\title{
Compositional devices in Six Chorale Preludes, Op. 41 (1938), by Paul Pisk
}

\section{Any Raquel Carvalho}

Abstract: The purpose of this article is to shed light on the compositional devices utilized in the organ work Six Chorale Preludes, Op. 41, by Paul Pisk. The analysis and discussion include cantus firmus treatment, motives derived from or related to the cantus firmus, and harmony and form, when they relate to the above. Chorale prelude types have been categorized according to those used by Bach. This study is aimed for organists as well other musicians, since the analytical aspects demonstrate the use of contrapuntal techniques in a composer who belonged to the Second Viennese School. Understanding how the chorale tune and its derivations are employed is essential for an organist to select registration, change manuals, and present a sound performance.

Resumo: O objetivo deste trabalho é apresentar as técnicas composicionais adotados na obra Six Chorale Preludes, Op. 41, para órgão, de Paul Pisk. A análise e discussão incluem o tratamento do cantus firmus, motivos derivados ou relacionados com o cantus firmus, harmonia e forma, na medida em que se relacionam com os itens anteriores. Os prelúdios corais foram categorizados conforme aqueles utilizados por Bach. Este estudo direciona-se a organistas e outros músicos, uma vez que os aspectos analíticos demonstram o uso de técnicas contrapontísticas por um compositor pertencente à Segunda Escola Vienense. Entender como a melodia coral e seus derivados são empregados é fundamental para o organista escolher a registração, trocar de manuais e apresentar uma execução coerente.

The purpose of this article is to shed light on the technical devices utilized in the organ works Six Chorale Preludes, Op. 41, by Paul Pisk. An analysis and discussion of this work include cantus firmus treatment, motives derived from or related to the cantus firmus, and harmony and form, only when they relate to the above. The chorale types have been categorized based on those by J.S.Bach 
(Stinson, 1999, p. 62-75). This study is aimed not only for organists, but other musicians as well, since the analytical aspects demonstrate the use of contrapuntal techniques in a composer who belonged to the Second Viennese School.

Paul Amadeus Pisk (1893-1990), a figure of importance in music history, belonged to the original group of composers and composition students who surrounded Arnold Schoenberg. Pisk composed modal, tonal and atonal works. Despite his association with Second Viennese School, only three of his over two hundred compositions adopt the 12-tone style, though the majority is atonal (Collins, 1972). Pisk received his doctorate in musicology from Vienna University (1916) under Guido Adler. A year later he studied composition privately with Arnold Schoenberg until 1919. He taught at the Vienna Academy, the New Vienna Conservatory, and the Austro-American Conservatory. He was coeditor and music editor of Musikblätter des Anbruch and the Arbeiter-Zeitung, respectively. Pisk served as board member, secretary, and pianist in Schoenberg's Society for Private Musical Performances and helped found the International Society for Contemporary Music. ${ }^{1}$ He is well-known for his book History of Music and Musical Style, along with Homer Ulrich (1963). In 1967 Pisk was awarded a golden doctoral diploma by the University of Vienna. As a professor, Pisk taught at Redlands University in California (1937-1951), the University of Texas (19511963) and Washington University in St. Louis (1963-1972), as well as teaching at frequent summer positions elsewhere.

Pisk began writing for the organ only after his arrival in the United States in 1936. Before that time, his involvement in the Schoenberg circle seems not to have provided him with the opportunity to compose organ works. Moreover, the demand for

Composer Paul Pisk - A Conversation with Bruce Dufie. http://www.bruceduffie.com/pisk.html Retrieved 10 Mar. 2015. 
organ music in Austria, a conservative Catholic country, was basically limited to music for church services (Fagundes, 1988, p. 3). Pisk composed eleven works for organ solo, an unusually large number for this medium if compared to the output of other members of the Second Viennese School. These works were written between 1938 and 1968, and are listed below (Figure 1). More than half of Pisk's organ works utilize cantus firmus treatment (marked with an asterick), as can be seen below:

Figure 1 - Table of organ works by Paul Pisk

\begin{tabular}{|l|l|l|}
\hline Composition & Opus no. & Date of composition \\
\hline Six Chorale Preludes* & 41 & 1938 \\
\hline Sonata for Organ & 46 & 1940 \\
\hline Phantasy on a Mexican Folk Song* & -- & 1941 \\
\hline Prelude, Adagio and Canzone & 56 & 1946 \\
\hline Suite for Organ & 64 & 1949 \\
\hline $\begin{array}{l}\text { Choral Fantasy on When / Survey the } \\
\text { Wondrous Cross * (Choral Fantasy on } \\
\text { Hamburg) }\end{array}$ & 73 & 1951 \\
\hline Prelude, Fugue and Hymn* & 79 & 1952 \\
\hline Three Pieces & 87 & 1955 \\
\hline Improvisation on an American Folk Melody* & 92 & 1957 \\
\hline Phantasy on Trotzlied of Josef Seyfried* & -- & $1961 / 62$ \\
\hline Processional for Organ & -- & 1968 \\
\hline
\end{tabular}

Understanding how the chorale tune and its derivations are employed is essential for an organist to select registration, change manuals, and present a sound performance. A discussion of the Six Chorale Preludes, all based on Protestant hymn tunes, follows. The main focus is on the melody and the motives derived from it, cantus firmus treatment, chorale type, and contrapuntal devices employed. 


\section{Chorale Prelude - Op. 41, No. 1}

The first chorale prelude, Heavenly Father, based on the hymn tune Unser Vater im Himmelreich, is a melody chorale, since the hymn tune appears as a continuous melody, uninterrupted by interludes. In a melody chorale, "the entire chorale tune is presented in the uppermost voice, in more or less continuous fashion and basically without embellishment" (Stinson, 1999, p. 62). Interludes of one to two measures are common between the phrases of the chorale tune.

The six-line Dorian melody, however, does not appear in its entirety; the fifth line has been omitted. The hymn tune, highlighted in the manuscript by the composer's own accent indication, is stated in the soprano in half-note values, except for the last line, which appears in the bass. The first cantus firmus line ${ }^{2}$ employs paraphrase technique in the uppermost voice, preceded by a short introduction. Pisk inserted a passing tone between the second and third cantus firmus notes of line 1 (Figure 2). According to Goetschius:

Although it is characteristic...to restrict the cantus firmus to the exact form of the original chorale, it is, nevertheless, both natural and desirable (especially in actual practice) to modify certain tones of the given melody by means of unessential passing- or neighboring-notes (Goetschius, 1975, p. 194).

Figure 2 - Chorale Prelude No. 1, Original and generated line $1^{3}$

a) Original cantus firmus, line 1

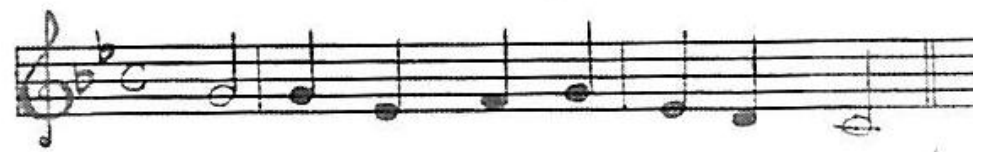

2 Here, cantus firmus relates to the original hymn tune lines.

3 All examples of Six Choral Preludes by Paul A. Pisk reprinted by permission of the American Composers Alliance, Inc. (BMI) and Harry Ransom Center, The University of Texas at Austin. 
b) Pisk's cantus firmus, line 1, mm. 3-7 (R.H.)

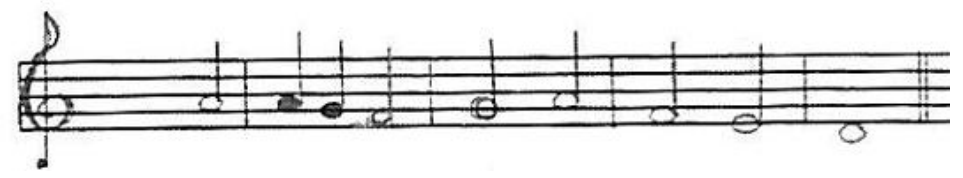

The cantus firmus is treated in unison (lines 1, 2, 3, 6), as well as in octave doublings (line 4). Free voice leading occurs in lines 1 and 2 (mm. 3-12), with the cantus firmus appearing first in the uppermost voice (line 1: mm. 3-5; line 2: $\mathrm{mm} .8-11$ ) and shifting to the intermediate part (line $1: \mathrm{mm} .5-7$; line $2: \mathrm{m} .11$ ) within the same line of the tune. The same register, however, is maintained throughout (Figure 3, mm. 3-7). This complex voice leading has been indicated by the composer by dotted lines ( $\mathrm{mm} .4-5)$ :

Figure 3 - Chorale Prelude No. 1, mm. 1-8
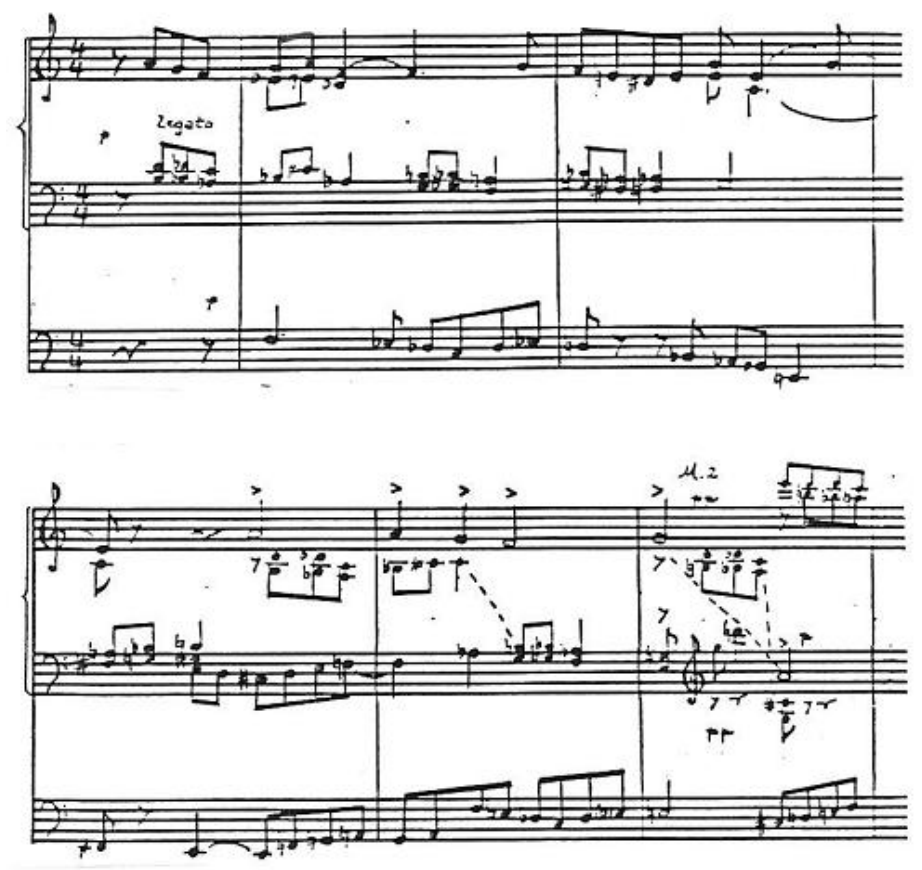
Figure 4 - Motivic development in Chorale Prelude No. 1: motives (circled) and added notes (rectangles)

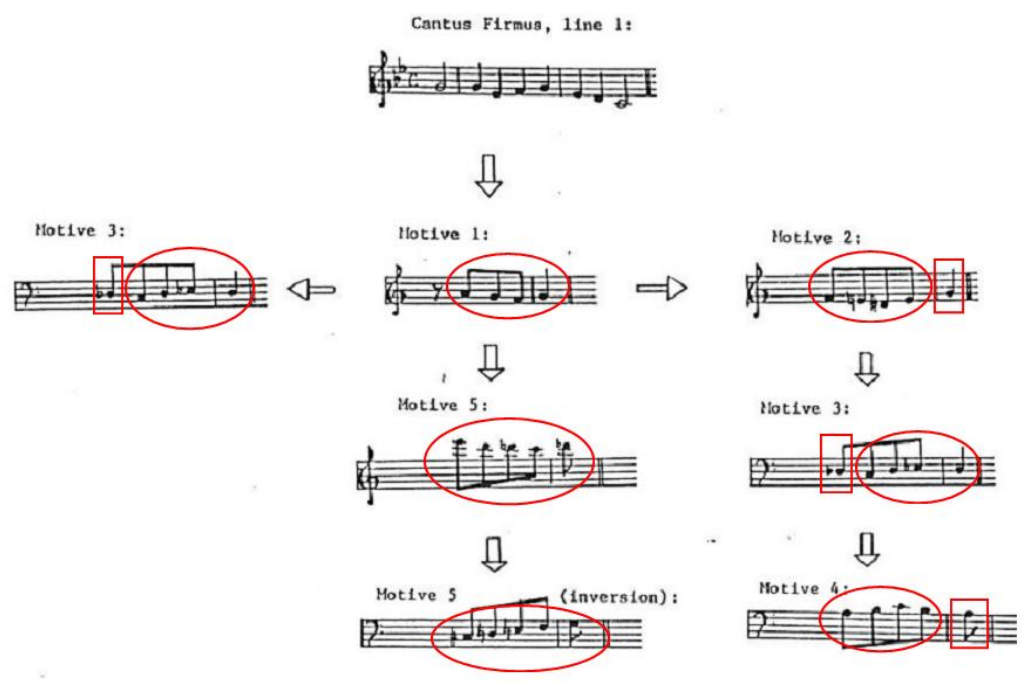

The first motive (1) in this piece is an upbeat figuration comprised of the first four notes of the composition (top voice). The last note is sometimes altered in order to accommodate the underlying harmony. The first appearance of this motive is diatonic, but most of the times it is a chromatic figuration:

Figure 5 - Chorale Prelude No. 1, Motive 1

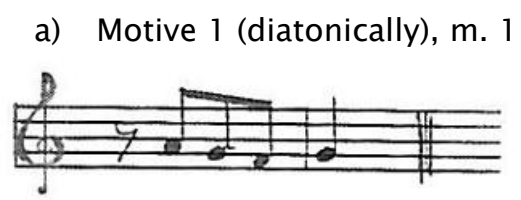

b) Motive 1 (chromatically), m. 1

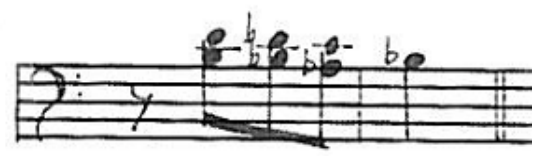

Motive 2, also in eighth notes, is identical to the first motive, but without the upbeat character. Motive 3 is the retrograde of motive 
2 , but may also be considered the inversion of the first motive (1) with an added note in the opposite direction in place of the rest. The inversion of motive 2 has been labeled motive 4 . The last motive (5) is an accented descending (or ascending) group of eighth notes, similar to motive 1 if a note were added to the beginning of the figuration). The long cantus firmus notes, along with the bass, govern the harmony in this chorale prelude. The harmony is governed by the long cantus firmus notes in relation to the bass. The tonic is D minor with cadences on D (m. 7), A (m. 12), B-flat (m. 17), A (m. 23), and D (m. 28).

This composition uses the unaltered cantus firmus in halfnote values with the omission of line 5 of the tune. All of the accompanying materials (motives 1-5) are based exclusively on the opening notes of the first line of the hymn tune. The motivic development is rhythmic with downbeat figures derived from the upbeat motive 1 . The simplicity of these motives results in a transparent motivic structure.

Although the cantus firmus appears in the uppermost voice in all lines except for the last, the conclusion of lines 1 and 2 contain material introduced in a higher register (mm. 5-8 and 11-12), derived from the opening motive of the left hand, and based on parallel thirds. Octave doublings occur in line 4 ( $\mathrm{mm}$. 19-24), with the last cantus firmus line (line 6) shifting to the bass voice (mm. 24-29) to terminate the piece in a lower and more dramatic register.

The chorale structure is symmetrical, as can be observed in Figure 6. Pisk inserted a short interlude in imitation between lines 3 and 4 , based on the opening motive in parallel thirds. This material also terminates the piece (codetta, mm. 29-32) with the return of the pedal motive exactly as in the opening measure, concluding with a Piccardy third, in the fashion of most chorales written in the minor mode. 
Figure 6 - Formal structure in Pisk's Chorale No. 1 (Op. 41)

\begin{tabular}{|l|r|r|r|r|r|r|r|r|}
\hline Section & Introd. & Line 1 & Line 2 & Line 3 & Interlude & Line 4 & Line 6 & Codetta \\
\hline $\begin{array}{l}\text { Measure } \\
\text { number }\end{array}$ & $1-3$ & $3-8$ & $8-13$ & $13-17$ & $17-19$ & $19-24$ & $24-29$ & $29-33$ \\
\hline $\begin{array}{l}\text { Number of } \\
\text { measures }\end{array}$ & 3 & 6 & 6 & 5 & 3 & 6 & 6 & 5 \\
\hline
\end{tabular}

Pisk's concept of unity, as stated by Collins is once more confirmed by his use of thematic and accompanying materials derived from an opening motive: "The concept of thematic continuity is basic to Pisk's style. He achieves unity in his works by stating a motive at the beginning of each composition and then deriving secondary themes and accompanying material from the motive." (Collins, 1972, p. 180).

This choral prelude is constructed upon chromaticism in such a way that it tends towards atonality. However, the employment of a chorale melody in the strict sense of a melody chorale enables one to perceive a general sense of tonality as a result of cadence points at the conclusion of each line. The abundance of non-functional chromaticism, often resulting from third and sixth doublings of the accompanying materials, has been utilized to create variety and interest in this composition. The harmony is defined by the relationship between the cantus firmus and the pedal notes. 


\section{Chorale Prelude No. 2}

The second chorale prelude, Hast Thou hidden thy face, uses the hymn tune "Hast du denn, Jesu, dein Antlitz gänzlich verborgen," an ornamented version of the better known tune Lobe den Herren (Praise to the Lord, the Almighty). Unlike Chorale Prelude No. 1, the entire tune is utilized as a cantus firmus, thus it falls into the cantus firmus chorale category4:

Figure 7 - Chorale Prelude No. 2. Chorale tune lines

\begin{tabular}{|l|l|}
\hline Line Number & Measure Number \\
\hline line 1 & $\mathrm{~mm} .19-24$ \\
\hline line 2 & $\mathrm{~mm} .31-36$ \\
\hline line $3 \mathrm{a}$ & $\mathrm{mm} .44-45$ \\
\hline line $3 \mathrm{~b}$ & $\mathrm{~mm} .51-53$ \\
\hline line 4 & $\mathrm{~mm} .81-86$ \\
\hline
\end{tabular}

The cantus firmus in this chorale prelude cannot be as easily discerned as in the previous one because it features the same rhythmic ratio as the motive derived from it. It begins with an introductory passage with the augmentation of line 1 in the pedal (mm. 1-18), closing when all voices come to a halt on a dotted halfnote, emphasized by the composer's fermata. The following Figure gives the original tune (Lobe den Herren) and the cantus firmus lines as used by Pisk (Figure 8).

4 The main traits of the cantus firmus chorale are "the presentation of the chorale tune generally in long notes and the separation of the phrases of the chorale tune by interludes ranging from one to ten measures in length..." (Tusler, 1968, p. 28). 
Figure 8 - Chorale Prelude No. 2, Original e generated line tunes

a) original tune, line 1

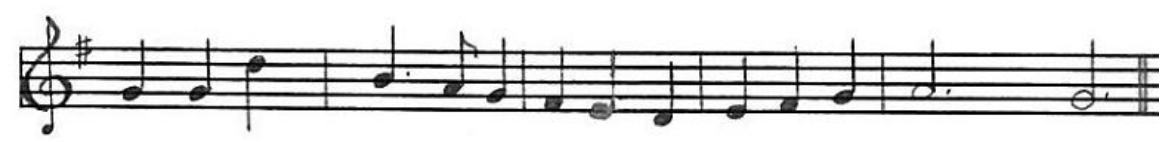

b) Pisk's cantus firmus, line 1, mm. 19-24

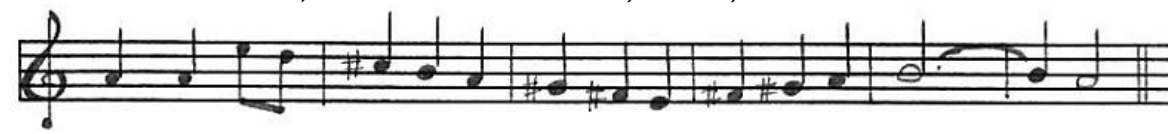

c) original tune, line 2

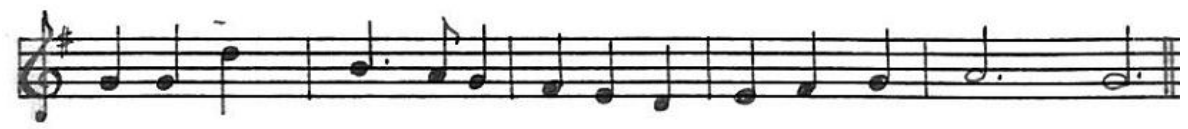

d) Pisk's cantus firmus, line 2, mm.31-36

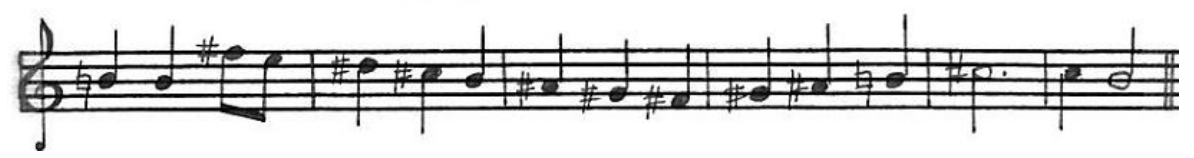

e) original tune, line 3

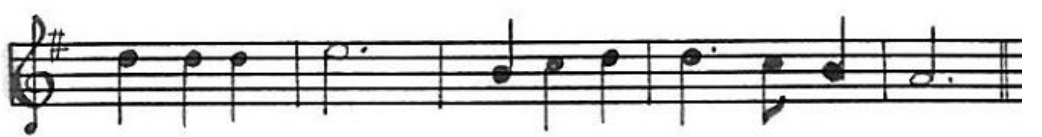

f) Pisk's cantus firmus, line $3, \mathrm{~mm} .44-45 ; 51-52$

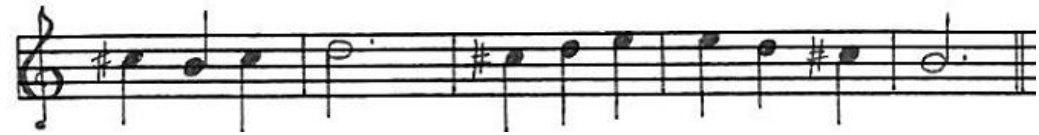

g) original tune, line 4

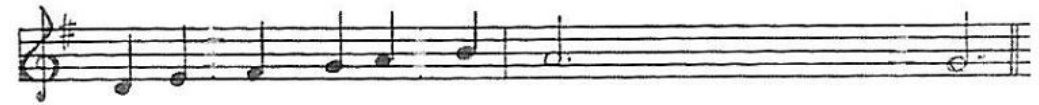

h) Pisk's cantus firmus, line 4, mm. 81-86

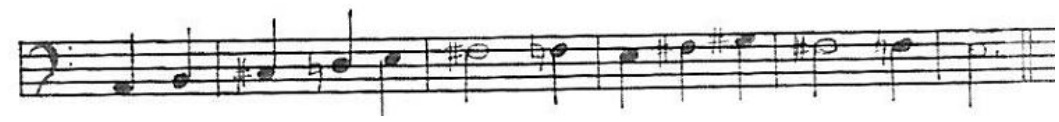

All four of the cantus firmus lines are in A major, except for the final one. Line 4 is melodically in D major, but harmonically in $A$ major (Figure 9). This, however, counterbalances the appearance of line 1 , also in $\mathrm{D}$ major, in augmentation in the pedal in mm. 4-18. A 
similar situation applies to chorale Prelude No.1 when the introductory passage recurs at the conclusion of the piece to round it off.

A lengthy interlude with accented pedal notes follows the statement of the third line of the tune $(\mathrm{mm}$. 54-77). The composer reintroduces the first line at the conclusion of the piece $(\mathrm{m} .78$, top voice), repeating it an octave higher simultaneously with line 4 in the upper L.H. voice in m. 81.

Figure 9 - Chorale Prelude No. 2, mm. 82-86

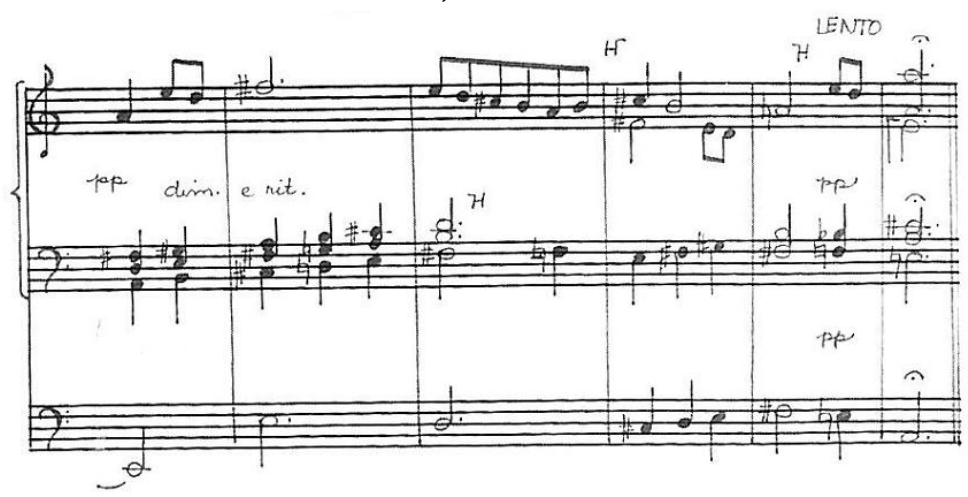

As mentioned, the motive that permeates this composition contains the same rhythmic ratio as the cantus firmus. This downbeat motive (motive 1) derived from the opening of line 1 of the hymn tune, always features a half note as its first note. It consists of either one measure plus one note, or two complete measures (Figure 10). Motive 1 is used in stretto in the opening, but on different pitch levels (Figure 11 ).

Figure 10 - Chorale Prelude No. 2, Original e generated line tune and motive 1
a) Cantus firmus, line 1

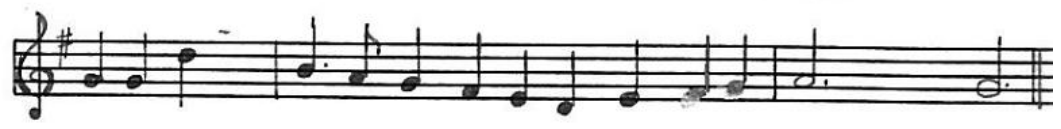


b) Pisk's cantus firmus, line 1, mm. 19-24 (R.H.)

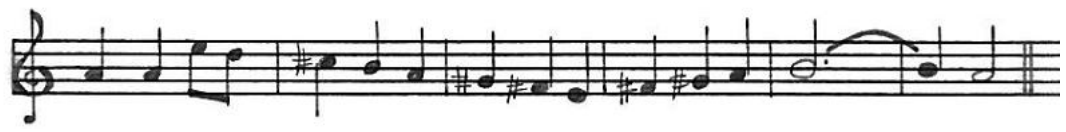

c) motive 1, mm. 1-2 (L.H.)

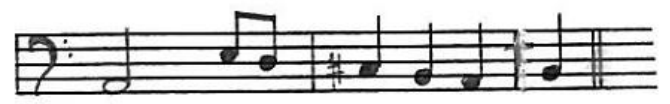

f) motive 1, mm. 4-5 (L.H.)

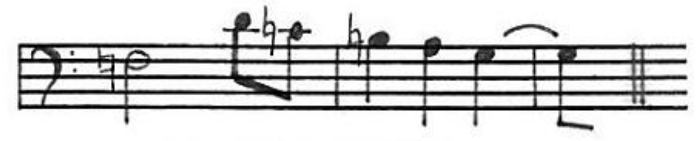

Figure 11 - Chorale Prelude No. 2, mm. 1-3, Motive 1 in stretto

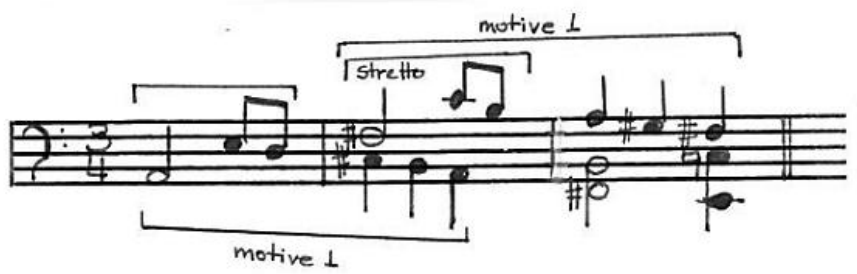

Besides employing augmentation of the first line of the cantus firmus in the opening $(\mathrm{mm} .4-18)$, Pisk uses another contrapuntal device, stretto, at the entrance of line 1 ( $\mathrm{mm}$. 19-20) and line 2 ( $\mathrm{mm}$. 32-33), each time on different pitches. The rhythmic character of this piece is defined by the continuous use of quarter notes and paired eighth notes (Figure 12), the last figure permeating all voices, though not simultaneously:

In addition, a rhythmic derivation of motive 1 can be seen in m. 15 (right hand; R.H.) and m. 16 (left hand; L.H.). This figuration does not contain the characteristic skip of motive 1 (Figure 13). 
Figure -12 Chorale Prelude No. 2, mm. 68-77
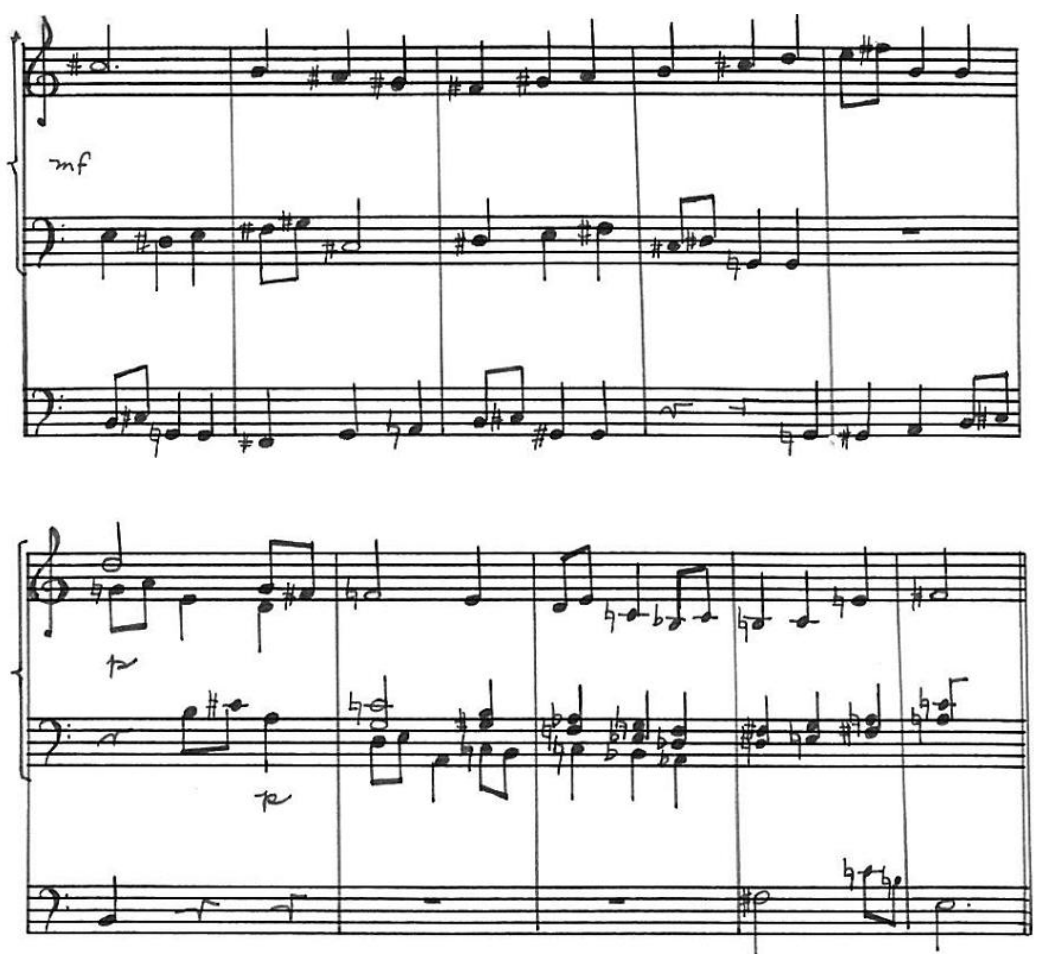

Figure 13 - Chorale Prelude No. 2, mm. 15-16

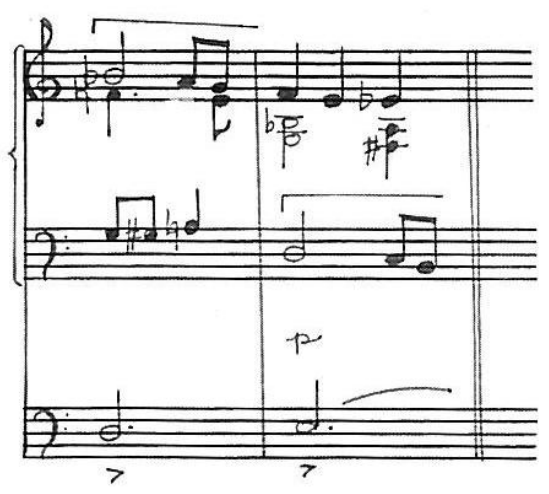

This chorale is less chromatic than the first. The formal structure of Chorale Prelude No. 1 includes the same material at the beginning and end of the composition. In Chorale Prelude No. 2, this 
is balanced by the emphasis on $D$ at the beginning (m. 4), with line 1 of the cantus firmus in augmentation at the end and the fourth line of the tune melodically in $\mathrm{D}$ major. The first line of the hymn melody recurs at the conclusion of the composition $(\mathrm{mm} .78-82)$ to round off the work. Stretto does not occur as a means of stabilizing the underlying harmony. The augmentation of the first line of the hymn tune in the opening of the work lengthens the harmonic passage in $D$ minor (mm. 4-18, pedal). This serves as an introduction to the tonic statement of line 1 (m. 19), thus forming a IV-I progression.

\section{Chorale Prelude No. 3}

The third chorale prelude, Oh, God and Lord, based on the hymn tune Ach Gott und Herr is a cantus firmus chorale ${ }^{5}$ with the entire melody appearing in augmented note values in alternation between the outer voices, beginning with the pedal. As in the preceding composition, the first half of line 1 is reintroduced at the close of the piece, this time in the pedal. Only the last line of the cantus firmus has been altered:

Figure 14 - Chorale Prelude No. 3, Original and generated line 4

a) original tune, line 4

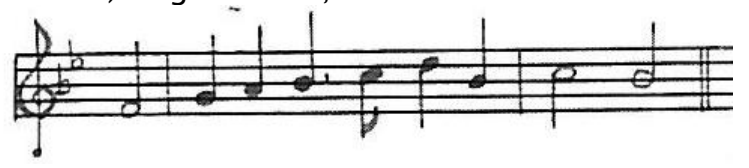

5 The main traits of the cantus firmus chorale are "the presentation of the chorale tune generally in long notes and the separation of the phrases of the chorale tune by interludes ranging from one to ten measures in length..." (Tusler, 1968, p. 28). 
b) Pisk's cantus firmus, line 4, mm. 51-58 (R.H.)

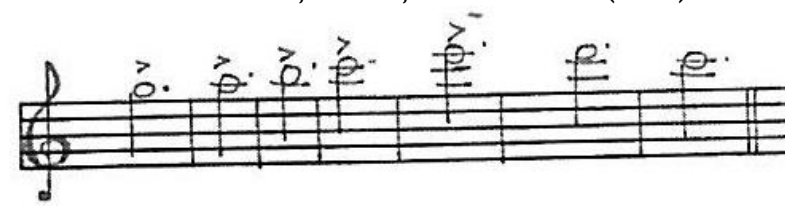

Three distinct accompanying materials appear in conjunction with the cantus firmus and have been labeled Motives 1, 2 and 3 :

Figure 15 - Motives in Chorale Prelude No. 3

\begin{tabular}{|c|l|}
\hline $\mathrm{mm} .1-21$ & $\mathrm{~mm} .22-29$ \\
\hline Line 1: pedal & Line 2: top voice \\
\hline Motives:1: $\mathrm{mm} \cdot 1-7$ & Motive 3: mm. 22-29 \\
2: $\mathrm{mm} .8-10$ & \\
$1: \mathrm{mm} .11-17$ & \\
$2: \mathrm{mm} .18-21$ & \\
\hline
\end{tabular}

\begin{tabular}{|c|c|}
\hline $\mathrm{mm} \cdot 30-50$ & mm. $51-68$ \\
\hline Line 3: pedal & Line 4: top voice \\
\hline Motives: 1: mm. 30-36 & Motive 3: mm. 51-57 \\
\hline $2: \mathrm{mm} \cdot 37-40$ & Line 1: mm. 58-64 \\
\hline 1: mm. 40-46 & Motives: 1: mm. 58-64 \\
\hline 2: mm. 47-50 & 2: $\mathrm{mm} \cdot 65-68$ \\
\hline
\end{tabular}

The first motive (Figure 16) is an ascending toccata-like, arpeggiated chord. This motive is absent in the statement of lines 2 and 4 of the tune. When it occurs in lines 1 and 3, it appears at the beginning of each line $(\mathrm{mm} .1-4 ; 30-33)$ and in the second half of these phrases (mm. 13-16; 40). The only exception is in $\mathrm{m}$. 45, when motive 1 is stated near the end of the cantus firmus line.

A second motive (motive 2, Figure 17), derived from the opening note of the first cantus firmus line (Figure 13a), and is used 
in imitation. It is a descending (or ascending) upbeat figure of three sixteenth notes followed by a longer note value. Two variants of this motive $(2 a, 2 b)$ consist of an alteration of the sixteenth notes. These three motives are unified by rhythm.

Figure 16 - Chorale Prelude, No. 3, motive 1

a) mm. 1-2

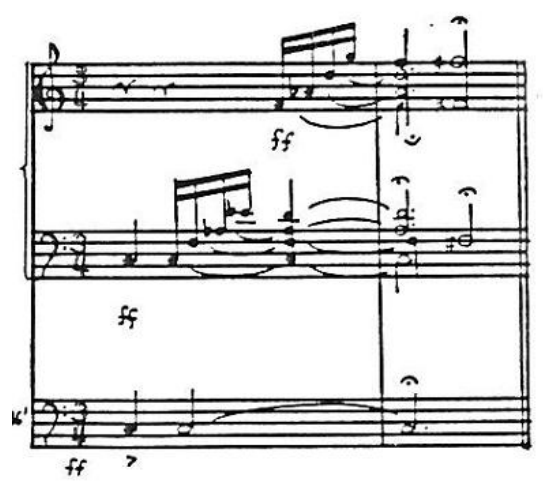

b) $\mathrm{mm} \cdot 15-16$

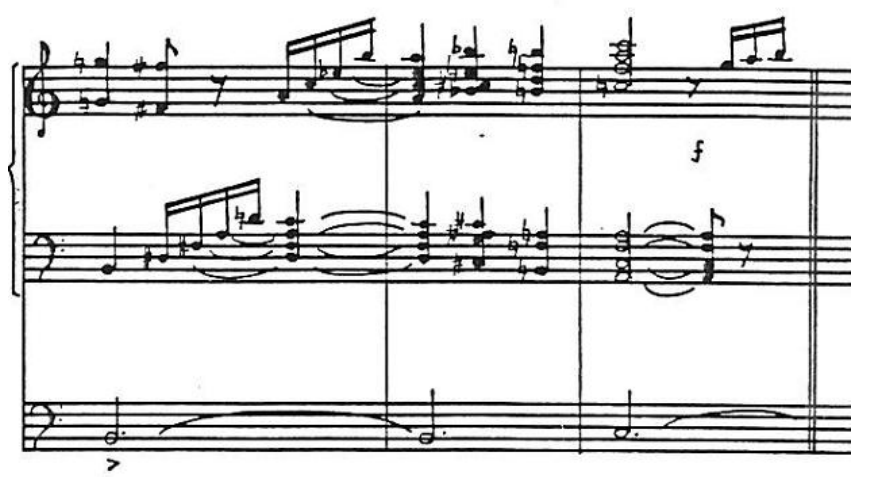


Figure 17 - Chorale Prelude No. 3, motive 2

a) motive $2, \mathrm{~mm}$. 8-9

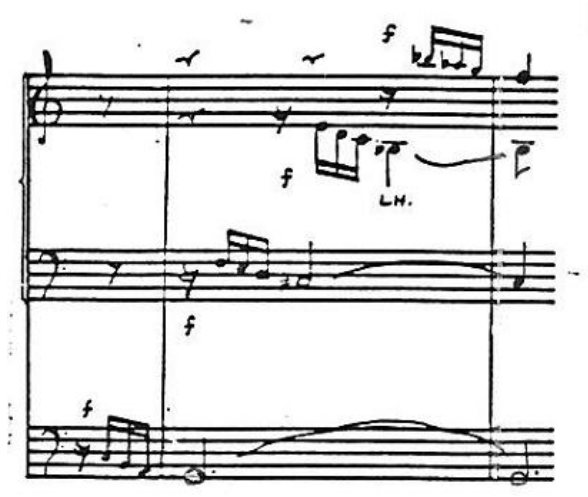

b) motive $2 \mathrm{a}, \mathrm{m} .37$

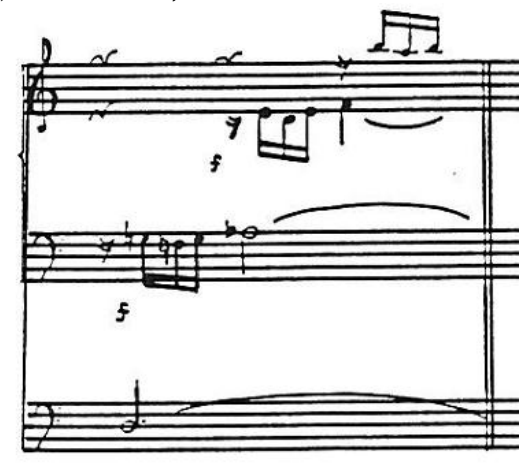

c) motive $2 \mathrm{~b}, \mathrm{~m} .47$

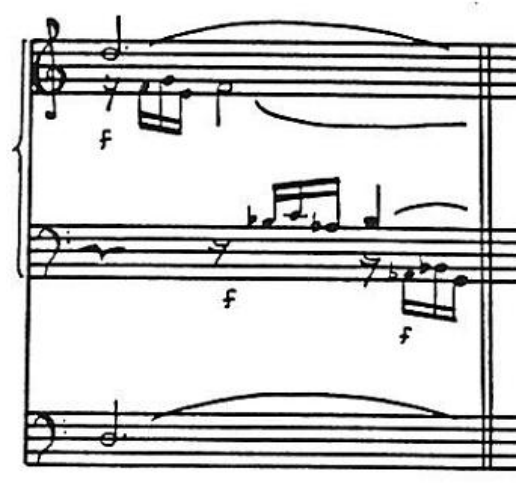

Like motive 1, motive 2 appears only when lines 1 and 3 are stated (in the pedal). A third motive (3) is used simultaneously with 
lines 2 and 4 (in the top voice) of the hymn tune. Motive 3 consists basically of stepwise eighth-note motion (Figure 18).

Figure 18 - Chorale Prelude No. 3, motive 3, mm. 22-29
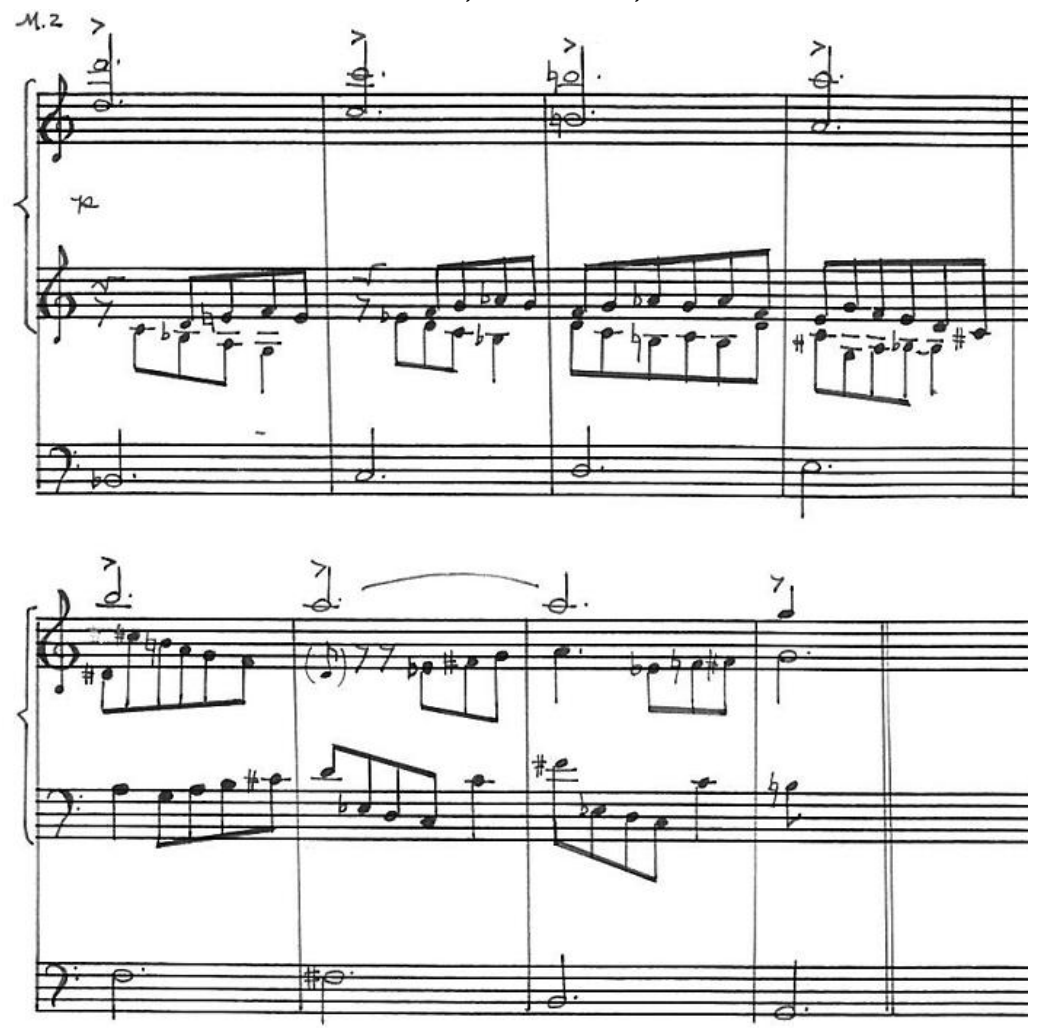

The contrapuntal devices used in this composition are augmentation of the cantus firmus and imitation. The first prolongs the tonic key (C), but the diminished seventh chords superimposed over this augmented pedal obscure the tonal center. Imitation procedures govern motive 2 and its variants.

Chromaticism is not a dominating element in this chorale prelude. In m. 57, a dominant seventh chord prepares the tonic key, and the opening portion of the composition is restated as a coda. The final dominant pedal on $\mathrm{G}(\mathrm{m} .64)$ features motive 2 just as in $\mathrm{mm}$. 8- 
10 , but now with octave doublings. The composer concludes with block chords that function cadentially.

\section{Chorale Prelude No. 4}

Chorale Prelude No. 4, Christ, He is my Life (Christus der ist mein Leben), is a melody chorale similar to Chorale Prelude No. 1. As in Chorale Prelude No. 3, the cantus firmus is heard in the outer voices. Lines 1 and 2 are stated in the pedal (mm. 16-18; 18-19) and then repeated in the same note values (quarter notes) a fourth higher, but this time in the top voice. Lines $3(\mathrm{~mm} .27-29)$ and $4(\mathrm{~mm} .31-$ 33) are then stated in the uppermost voice and a four-measure extension is added to establish the tonic (F).

Line 1 is restated in diminution in $\mathrm{mm}$. 20-21 the left hand. Only the second line of the cantus firmus adheres to the original melody. Pisk used a skip of a fourth after the fourth note of line 1 and added a passing tone before the last note (Figure 19). In line 3, the changes are not significant, but the fourth line has been modified to a greater extent (Figure 20).

Figure 19 - Chorale Prelude No. 4. Original e generated line 1

a) original cantus firmus, line 1

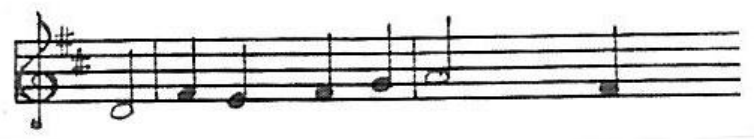

b) Pisk's line 1

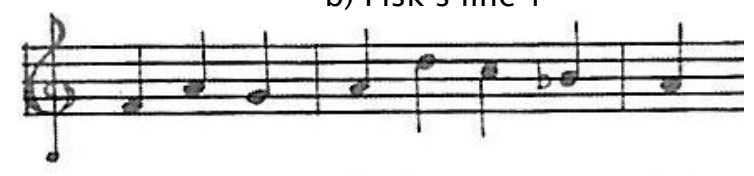


Figure 20 - Chorale Prelude No. 4, Original and generated line 4

a) original cantus firmus, line 4

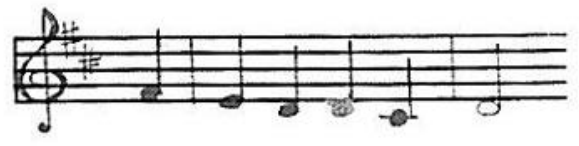

b) Pisk's line 4

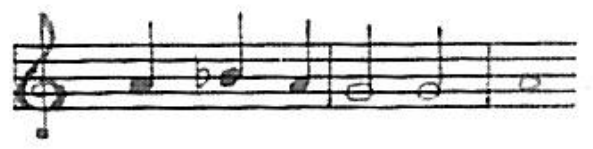

The first appearance of the cantus firmus is preceded by a fifteen-measure introduction. This passage contains two distinct motives. The first (motive 1) is an upbeat sixteenth-note figuration (Figure 21) which is the diminution of all four cantus firmus lines. This motive is presented throughout the composition, appearing also in the next slower ratio (eighth notes, m. 13).

Figure 21 - Chorale Prelude No. 4, motive 1

a) Pisk' s cantus firmus, line 1-4

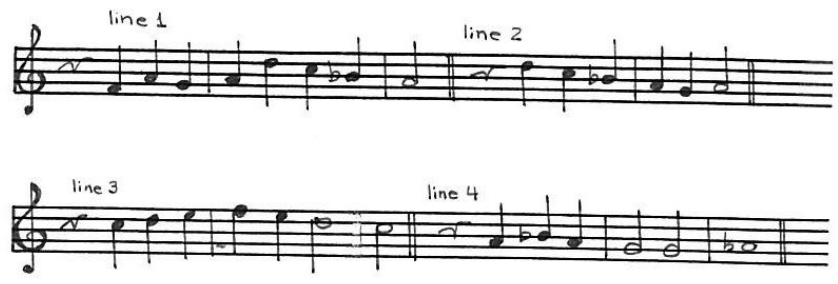

b) Motive 1:mm. 1-2, top voice
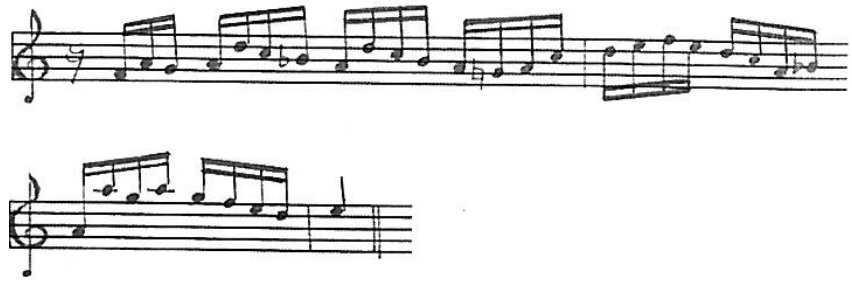
The second motive (motive 2), introduced in the opening section of this chorale prelude, is a much slower moving figuration used in invertible counterpoint with motive 1 . Motive 2 is not derived from the cantus firmus (Figure 22).

Figure 22 - Chorale Prelude No. 4, motive 2, mm. 1-3
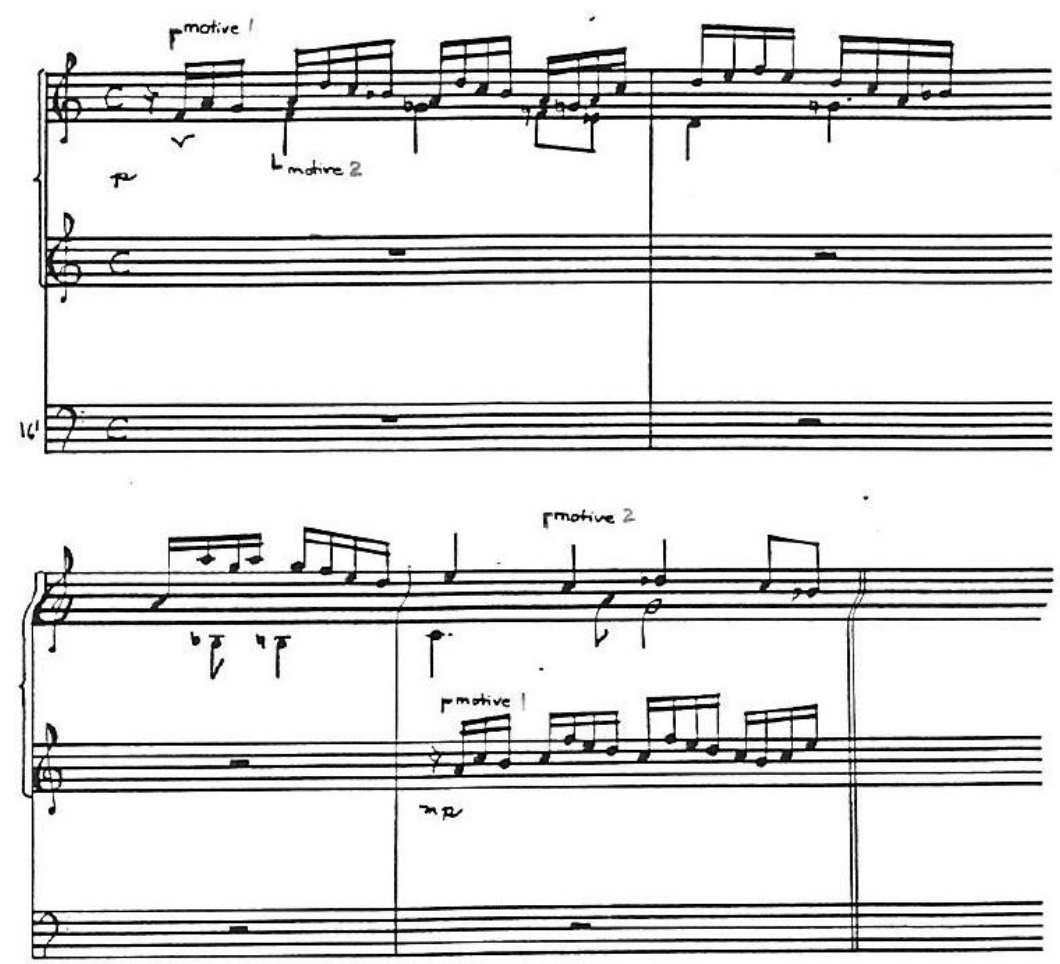

As in the previous compositions, the opening material returns at the conclusion of the work (m. 34) as a coda. Imitation appears at the outset of the piece $(\mathrm{mm} .1-2)$ and is restated in invertible counterpoint in mm. 3-4: 
Figure 23 - Chorale Prelude No. 4, mm. 1-8, use of imitation
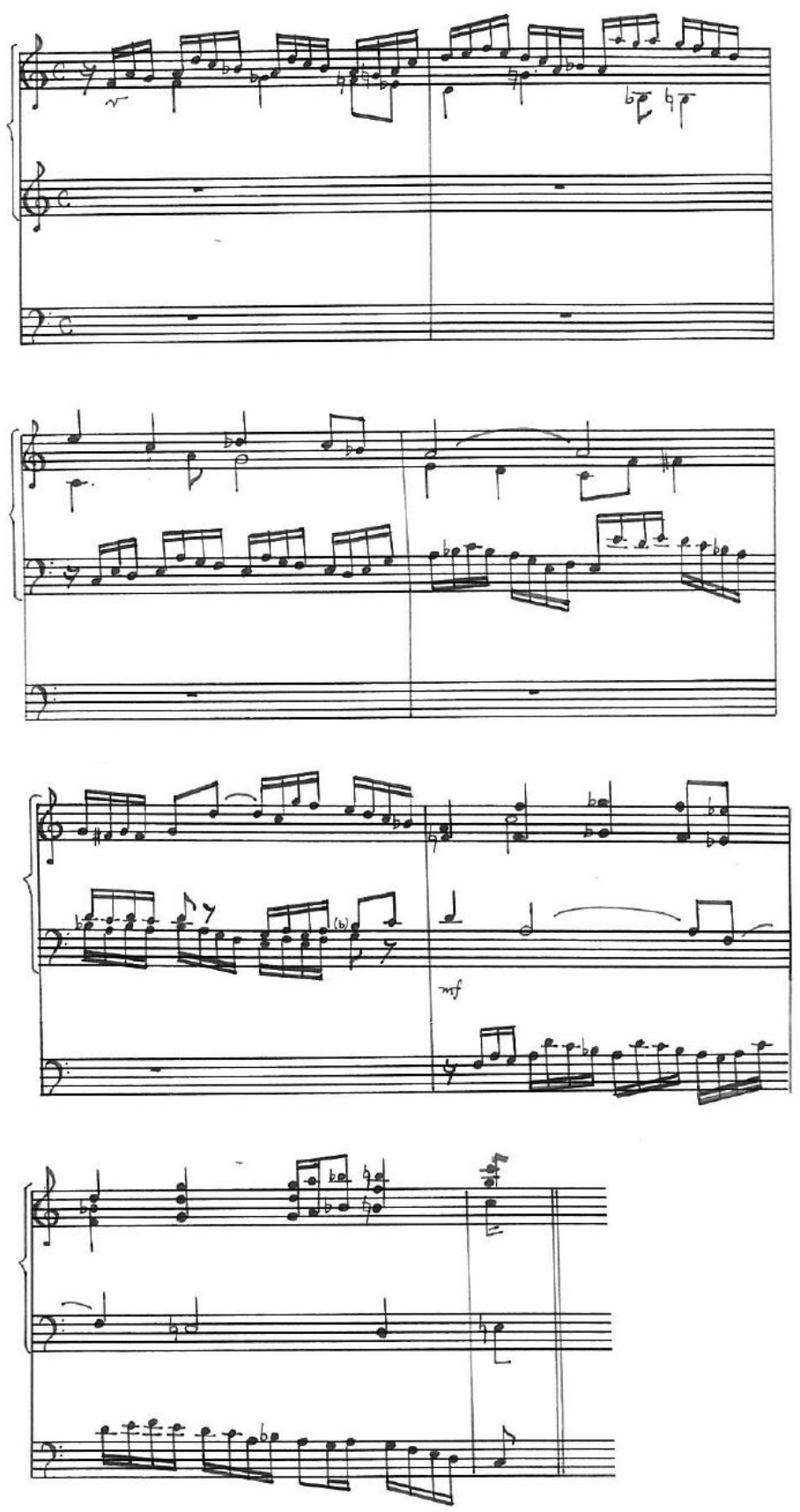

Motive 1 also appears in augmentation in the next slower ratio, and motives 1 and 2 are then combined in stretto, a procedure 
that recurs frequently. The initial cantus firmus statement of line 1 in the pedal (m. 16) occurs in stretto at the ratio of the quarter note, eighth note, and sixteenth note (Figure 20). Similar usage of stretto is also apparent in mm. 20-21 when double diminution occurs.

Figure 24 - Chorale Prelude No. 4, mm. 16-19
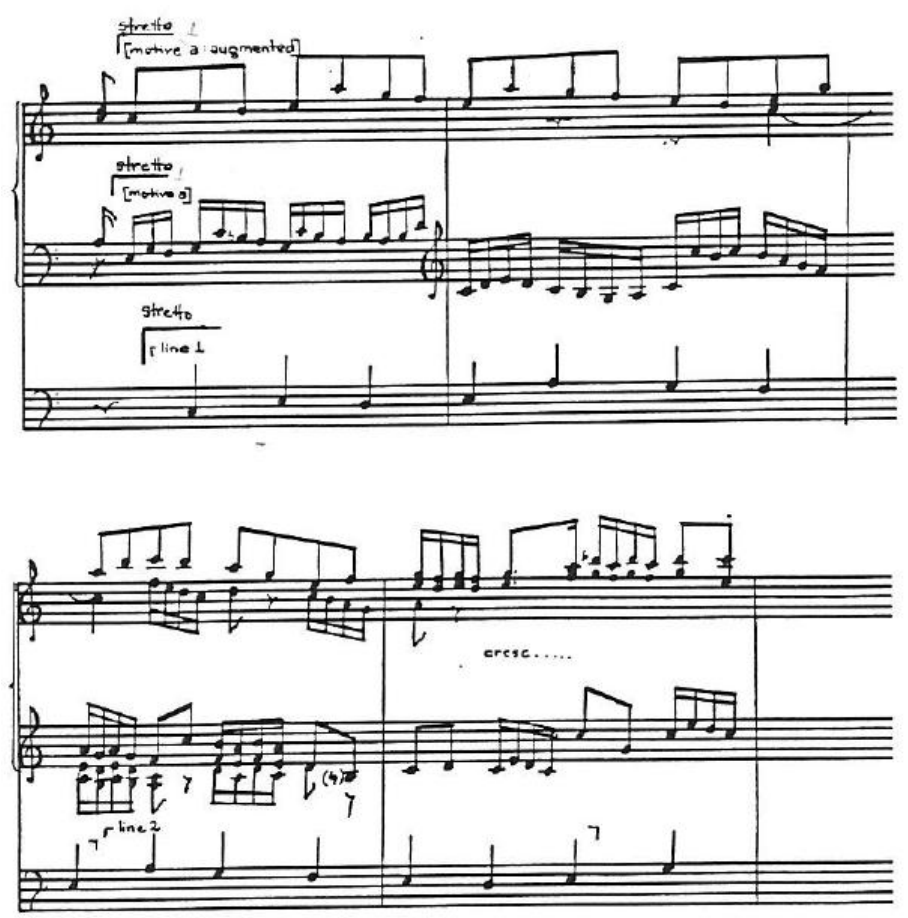

The tonic of this composition is F, but the first two lines of the cantus firmus are introduced on the dominant (mm. 16-19, pedal). When the cantus firmus shifts to the top voice, it is given in the tonic key. A deceptive cadence is reached after the statement of the fourth cantus firmus line (m. 33), and is followed by an extension to confirm the tonic.

This chorale prelude is similar to No. 2 in that the first line, or in this case the first two lines, of the hymn tune is heard in a different voice before the successive presentation of the entire cantus firmus. 
The two motives in this piece appear in invertible counterpoint (Figure 25), a device used to prolong the harmonic chords (mm. 1-8). This procedure can be considered a harmonic/motivic development, with the immediate repetition correspondingly transposed (mm. 1-4) and repeated ( $\mathrm{mm} .6-9)$.

Figure 25 - Chorale Prelude No. 4: use of invertible counterpoint

\begin{tabular}{|l|l|l|}
\hline mm. 1-3 & mm. 3-5 & mm. 8-10 \\
\hline Motive a & Motive $b$ transposed & $\begin{array}{l}\text { Motive a } \\
\text { (original) }\end{array}$ \\
\hline Motive $b$ & Motive a transposed & Motive $b$ \\
\hline
\end{tabular}

\section{Chorale Prelude No. 5}

The fifth chorale prelude, Now, as the day is over, based on the tune Nun sich der Tag geendet hat, is the shortest of the set. Like Chorale Preludes 1 and 4 , it is also a melody chorale. The cantus firmus appears in long note values in the top voice, with the repetition of line 1 at the conclusion of the work. The original tune has been altered in all but the first line, although the harmonic implications remain the same:

Figure 26 - Chorale Prelude No. 5, Original e generated line tunes

a) original cantus firmus, line 2

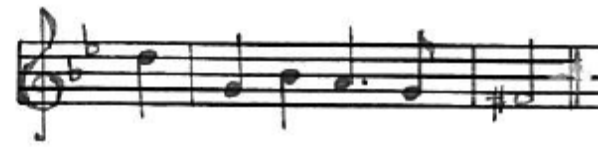

b) Pisk's line 2

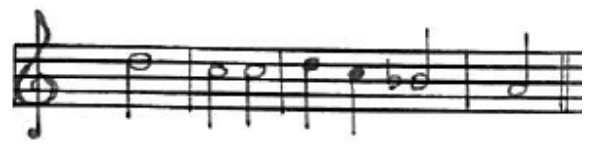


c) original cantus firmus, line 3

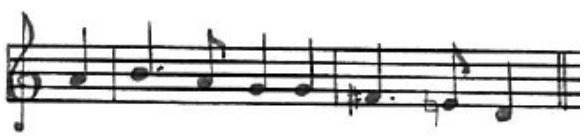

c) Pisk's line 3

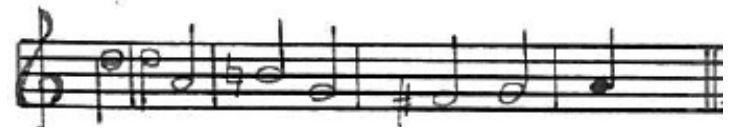

e) original cantus firmus, line 4

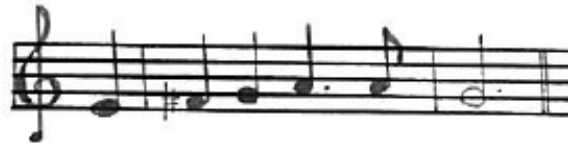

d) Pisk's line 4

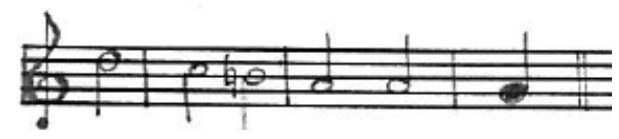

This chorale composition is the only one of the set in which all of the motives are unrelated to the cantus firmus. Motive 1 is a syncopated two-note "sigh" figure6 employed in the left hand throughout most of the piece (Figure 27). This upbeat motive is counterbalanced by straight quarter-note motion on the beat.

The other motive in this composition (motive 2 ) is a downbeat eighth-note figure with alternating ascending steps and falling thirds. It occurs simultaneously with block chords, however, motives 1 and 2 are never combined (Figure 28).

This chorale prelude in $G$ minor features extensive use of chromaticism as a result of the pitch content of motive 1 (see Figure 22). Distinct cadences are perceptible at the end of each cantus firmus statement with cadences on V (m. 4), ii (m. 9), V 6/V (m. 15), and iv (m. 20). The return of the first line of the hymn tune ends on a deceptive cadence (m. 26) of the parallel tonic, and the last cantus firmus note is implied (mm. 26-27) and extended for the remainder of the piece (mm. 28-29).

6 This figure usually depicts grief (Stinson, p. 61;67). 
Figure 27 - Chorale Prelude No. 5, motive 1, mm. 1-6
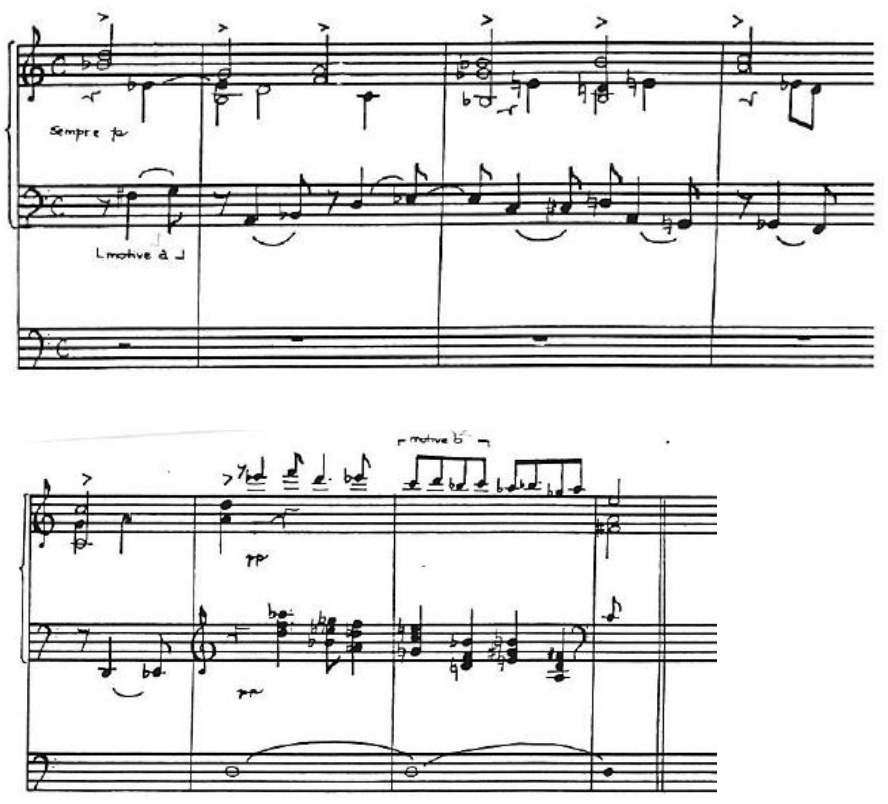

Figure 28 - Chorale Prelude No. 5, motive 2, mm. 5-6

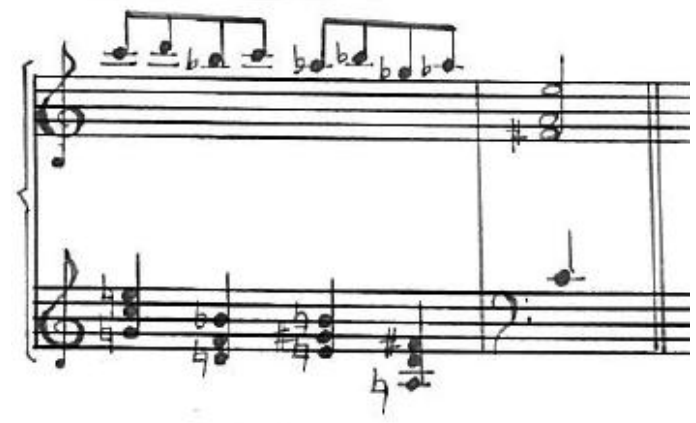

The simplicity of this chorale prelude, compensated for by extensive chromaticism, reflects the contemplative character of this evening hymn. Motive 1 is of greater rhythmic importance, while the second motive is significant because of its pitches. The character of 
this composition is also influenced by the lack of counterpoint and the many harmonic reference points.

\section{Chorale Prelude No. 6}

Chorale Prelude No. 6, Ah, Lord, I have acted badly, based on the hymn tune Ach Herr, ich habe missgehandelt, is a chorale canon. The four lines of the tune are utilized as a cantus firmus in canon between the left hand and pedal. Again, line 1 recurs at the conclusion of the piece as in Chorale Preludes 2, 3, and 5. Line 2 is the only one that has not been melodically altered. However, in lines 3 and 4, the changes are insignificant because only one note has been changed in each case. The first line contains more alterations:

Figure 29 - Chorale Prelude No. 6. Original and generated line tunes

a) original cantus firmus, line 1

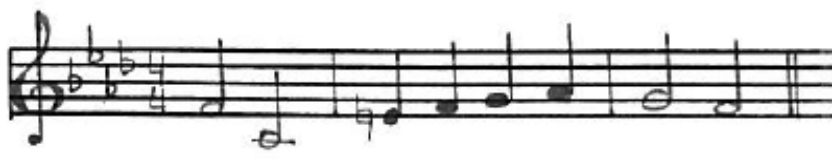

b) Pisk's line 1

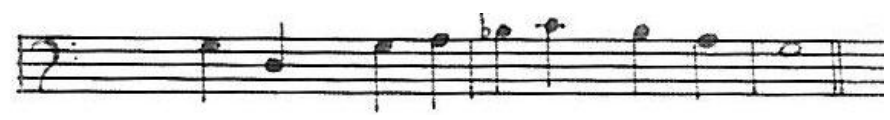

The two motives used in this chorale prelude are derived from the cantus firmus. Motive 1, a sixteenth-note figuration, is the diminution of line 1 of the hymn tune. It is utilized as a perpetuum mobile figuration, a retrospective procedure of the Baroque period. As can be observed in the figure below, the three opening notes in the left hand (motive 2), functioning as a head motive, are quoted verbatim from the first line of the hymn tune (Figure 30). 
Figure 30 - Chorale Prelude No. 6, motives 1 and 2

a) Pisk's cantus firmus, line 1

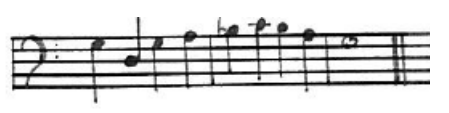

b) Motives 1 and 2, mm. 1-3

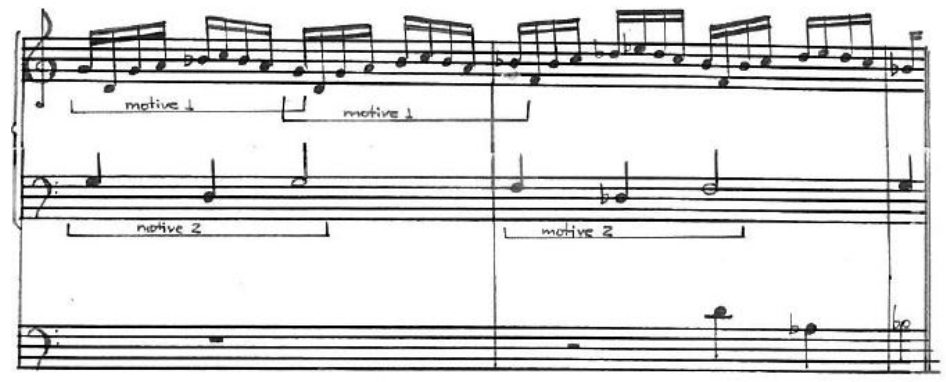

Perhaps the most important aspect of this piece is the canonic treatment of the cantus firmus lines. Whenever this canon occurs, the texture is maintained in strict three-voice writing, whereas one or more voices are added in the non-canonic interludes. Motive 1 is employed during the cantus firmus statements. Motive 2 opens each interlude (m. 8-10,13-16, 20-22, 26-29) in combination with the ever-present motive 1 .

The harmonic language is governed by the canons with the five opening notes, or by motive 1 outlining the chords. Although the composition begins in $\mathrm{G}$ minor, the parallel key, introduced in $\mathrm{m} .26$, dominates the remainder of the piece. A two-measure extension reinforces the tonic (mm. 34-35).

Chorale Prelude No. 6 is the most complex of the set. Its emphasis is on counterpoint (canon), with motives derived from the opening line of the cantus firmus, thus demonstrating the composer's ability to develop a complex piece from non-contrasting materials. Unlike the return of the opening lines of the hymn tunes at the end of 
other chorales, this return in Pisk's final piece of the set is intensified by the addition of a third and fourth canonic entrance (also in the tonic, m. 31). This approach resulted in a thicker texture (Figure 30), further intensified by the composer's dynamic indications ranging from piano to fortissimo. The last two and one-half measures then feature a very quick return to piano, but lead the R.H. to an extremely high texture, concluding the piece and the whole set in a most effective and unusual manner (Figure 31 ).

Figure 31 - Chorale Prelude No. 6, mm. 30-35
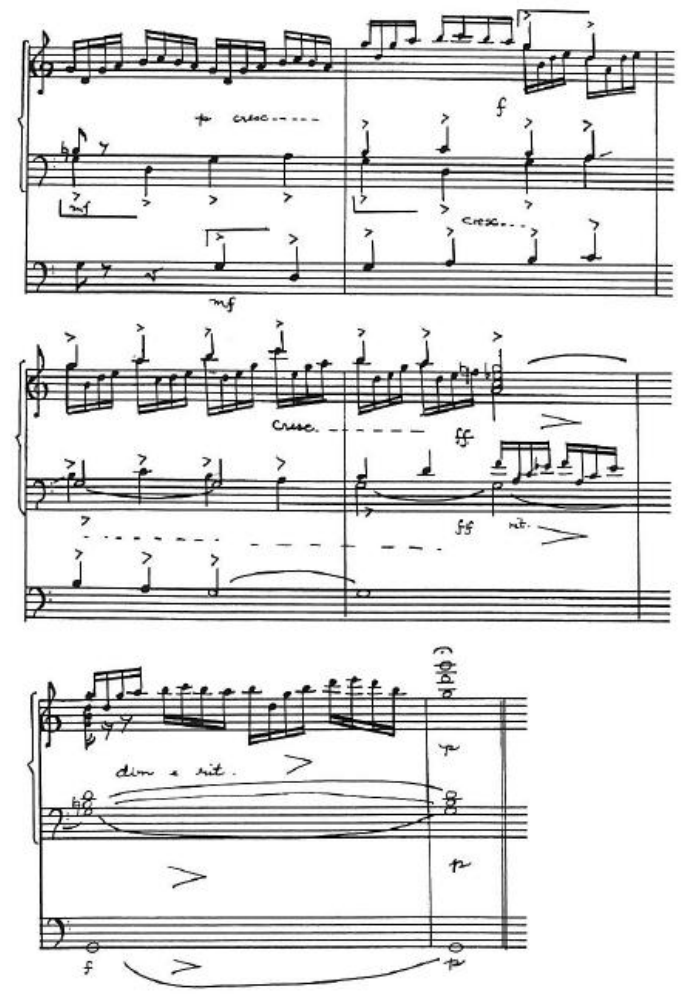

\section{Conclusion}

Paul Pisk combines retrospective characteristics in his Six Chorale Preludes through the employment of cantus firmi, as well as 
contrapuntal skills such as augmentation, diminution, imitation, stretto, and invertible counterpoint. His non-conservative style is depicted by obscuring tonality, resulting from abundant chromaticism and fewer traditional cadences. The analysis of this work enables the organist to make decisions concerning registration, manual changes and interpretation, as well as demonstrating Pisk's contrasting style, when compared to other members of the Second Viennese School.

\section{References}

COLLINS, Thomas William. The Instrumental Music of Paul A. Pisk. Doctoral Dissertation. University of Missouri. Lawrence, KS, USA, 1972.

DUFFIE, Bruce. A Conversation with Bruce Duffie. Interview. http://www.bruceduffie.com/pisk.html. Retrieved 10 Mar. 2015.

FAGUNDES, Any Raquel Carvalho. Cantus Firmus Treatment in Paul A. Pisk's Choral Fantasy, Op. 73. Doctoral Dissertation. University of Georgia. Athens, GA, USA, 1988.

GOETSCHIUS, Percy. Counterpoint applied in the invention, fugue, canon, and other polyphonic forms. Westport, Connecticut: Greenwood Press, 1975;

STINSON, Russell. Bach: The Orgelbüchlein. Oxford: Oxford University Press, 1999.

TUSLER, Robert L. The Style of J.S. Bach's Chorale Preludes. New York: Da Capo Press, 1968. 